\title{
PENGARUH KEEFEKTIFAN KEPEMIMPINAN KEPALA SEKOLAH TERHADAP KINERJA GURU SEKOLAH MENENGAH KEJURUAN NEGERI 31 (SMKN 31) JAKARTA-PUSAT
}

\author{
Dewi Nurmalasari*
}

\begin{abstract}
The objectives of this research was identify the effect of leadership effectiveness to teacher performance. The design of this research applies survey method. The responden are teacher at thirty one vocational high school (SMKN 31) with 55 teacher. Data analysis condition used normality test using skewness-kurtosis value used to know how normal data distribution in each variable represent by gradient. The result of this research conclude that there is positive effect leadership effectiveness to teacher performance with coefficient correlation $r X_{1} Y_{1}=0.933$ determination correlation 0.869 which showed variance $86.9 \%$. From this research conclude that leadership effectiveness giving significant contribution on employee performance. The result showed that variable can be good predictor to employee performance.
\end{abstract}

Keywords: headmaster leadership effectiveness, teachers performance

\section{ENDAHULUAN}

Seiring

perkembangan

menuntut perkembangan yang

pesat dalam dunia

pendidikan.Perkembangan dalam

dunia pendidikan sendiri berfungsi untuk mengembangkan potensi para siswa-siswi sebagai generasi penerus pengisi era globalisasi.Perkembangan potensi/ kemampuan siswa-siswi tidak bisa dipisahkan dari peran seorang guru.

* Dewi Nurmalasari. Dosen Fakultas Ekonomi Universitas Negeri Jakarta.

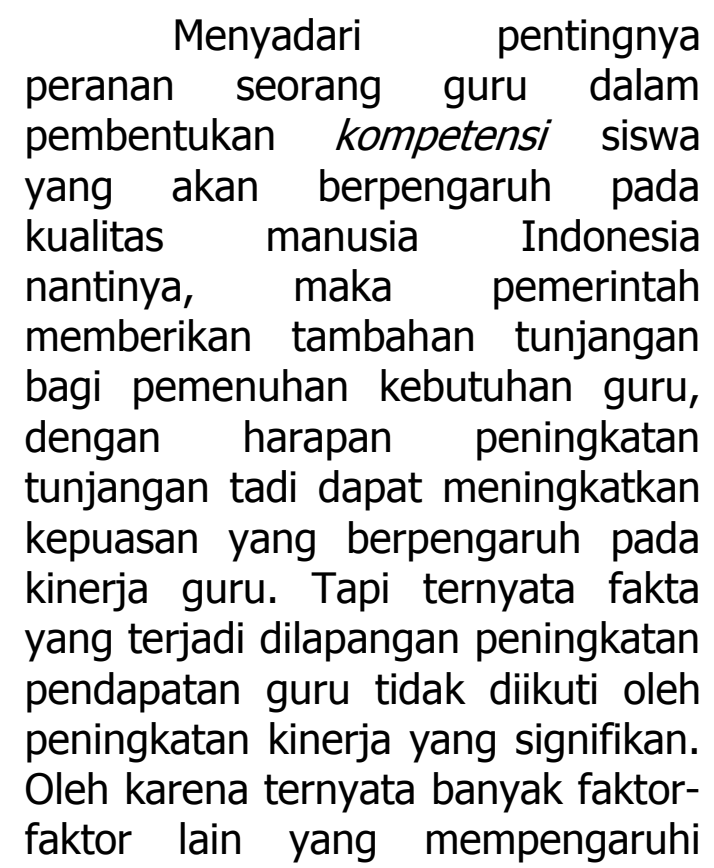


peningkatan kinerja seseorang selain pendapatan, antara lain adalah kepemimpinan kepala sekolah.

Kemampuan kepala sekolah untuk mengorganisasikan segala kegiatan sekolah dan mengarahkan guru-guru serta staf lainnya berpengaruh terhadap kemampuan mengajar guru dalam hal merencanakan, melakukan pengajaran dan mengevaluasi pengajaran.Pengorganisasian yang merupakan salah satu tanggung jawab kepala sekolah bertujuan agar guru-guru dapat bekerja secara efektif dalam satu kesatuan kerja yang kompak dan tepat, karena pengorganisasian merupakan dasar penyatuan sumber daya manusia dengan cara teratur serta mengatur orang-orang sedemikian rupa, sehingga mereka dapat mencapai tujuan-tujuan yang ditetapkan. Selain itu kepala sekolah juga harus mampu merumuskan berbagai jenis pekerjaan.Seiring dengan perkembangan jaman, guru dipaksa untuk maju dan mampu mengembangkan dirinya. Salah satu cara pengembalian diri guru adalah melalui pembagian (pengkordinasian) dan pengarahan pekerjaan yang tepat, yang dilakukan oleh kepala sekolah. Sesuai dengan tuntutan pemerintah yang menginginkan guru yang professional dan kompeten di bidangnya guna memberikan kinerja yang maksimal dalam meningkatkan kualitas siswa-siswi nantinya. Oleh karena itu maka seorang kepala sekolah harus mampu merumuskan kegiatan apa saja yang harus dikerjakan, kemudian menspesifikasikannya (job specification) agar lebih mengkhusus pada pelaksanaan kegiatan belajar-mengajar, serta membuat daftar kegiatan-kegiatan yang berupa uraian pekerjaan (job description) guna menciptakan guru yang lebih ahli dan professional dalam bidangnya.

Masalah pengarahan

personil merupakan tugas dan tanggung jawab kepala sekolah dalam usaha memelihara, menjaga dan memajukan organisasi sekolah, agar kegiatan-kegiatan dalam organisasi tersebut tidak terlepas dari rencana yang telah ditetapkan (Nawawi, 1994). Memelihara dan menjaga adalah memberikan pengarahan berupa kegiatan teknis yangtepat dalam mendayagunakan personil.

Guru-guru yang diberi
petunjuk tentang teknis
pelaksanaan pekerjaan secara jelas
dan realistis akan memberikan
motivasi internal dalam peningkatan
mutu pekerjaan (Hackman \&
Oldham's dalam Sergovanni, 1997).
Dengan demikian adanya
pengarahan yang baik dari kepala
sekolah akan menciptakan kondisi
yang menyenangkan dan
memungkinkan tercapainya tujuan
pendidikan secara keseluruhan.
Kepala sekolah yang efektif banyak
menggunakan waktunya dalam
bidang (1) $\begin{array}{ll}\text { pengembangan } \\ \text { program, dan (2) pengembangan }\end{array}$


professional. Disimpimpulkan bahwa lebih banyak waktu yang mereka habiskan untuk kepentingan kepemimpinan seperti pendapat Sergiovanni (1997) bahwa kepala sekolah yang baik dapat menggunakan waktunya untuk berkomunikasi, kegiatan-kegiatan kepemimpinan seperti memberikan pengarahan, petunjuk kepada guruguru demi keberhasilan.

Efektifitas kepala sekolah dalam hubungannya dengan pengarahan personil Nampak pada tingkat kesungguhan para guru untuk melaksanakan tugasnya dengan baik, semakin positif tingkah laku guru melaksanakan tugas mengajarnya berarti semakin berhasil pula pengarahan yang dilakukan.Perilaku guru diharapkan didalam kelas adalah perilaku yang dapat mengembangkan kreatifitas para siswa. Pengarahan guru dalam melaksanakan tugas mengajarnya menjadi efektif, apabila diarahkan pada pemberian bimbingan, mengarahkan dan menjelaskan perintah, memberikan petunjuk teknis, memberikan kesempatan untuk meningkatkan kemampuan dan keahliannya melalui on the job training serta memberi koreksi atas pelaksanaan tugas.

Untuk mengembangkan kemampuan guru yang lebih baik, perlu kepala sekolah yang benarbenar mengetahui dengan baik apa yang akan dikerjakan, siapa yang mengerjakan. Dimana pemimpin mampu memberikan dorongan yang besar bagi pegawainya untuk berprestasi, mempunyai semangat kerja dan kinerja tinggi yang berakibat pada rendahnya pegawai yang meninggalkan pekerjaan.

\section{KAJIAN TEORI Efektif}

Banyak perusahaan, institusi
hingga organisasi menetapkan tujuan pekerjaannya secara efektif dan efisien, kata-kata yang banyak dijadikan indikator keberhasilan oleh para pelaku didalamnya.Efektif menjadi sebuah kata yang begitu berharga, adapun pengertian efektif menurut Richard (2006) adalah Sejauh mana organisasi mencapai tujuan yang telah ditetapkan sebelumnya.penetapan tujuan disini dilakukan pada saat awal sebuah program direncanakan.

\section{Sedangkan menurut} pendapat Robert (2001) efektif adalah melakukan hal yang benar, melalui kemampuan memilih tujuan yang sesuai dan cara menyelesaikannya. Dari definisi ini kita dapat melihat bahwa terdapat tiga kata kunci penting yaitu bahwa efektif berawal dari pembuatan perencanaan, melakukan perencanaan tersebut dengan cara yang benar dan tujuan yang tepat sesuai dengan cara pencapaiannya. Jika ditelaah dari definisi ini, berarti para pelaku didalam sebuah program harus benar benar memikirkan segala aspek yang terkait mulai dari perencanaan hingga pencapaian tujuan sedari awal dimulainya sebuah program, 
guna menghasilkan program yang efektif

\section{Kepemimpinan}

Pemimpin adalah sebuah kata yang begitu identik dengan kekuasaan dan perintah, pemimpin menjadi sosok yang begitu disegani dan menjadi posisi yang banyak diinginkan oleh banyak pihak.Perebutan kekuasaan karena posisi pemimpin adalah posisi yang hanya ada beberapa buah saja dalam sebuah organisasi. Seorang pemimpin yang baik tentu harus mampu menjalankan fungsi fungsi kepemimpinan, adapun definisi kepemimpinan menurut megan (2005) adalah : individu yang ada dalam sebuah kelompok yang diberi tugas untuk mengatur dan mengkordinasikan aktifitas-aktifitas kelompok yang berhubungan dengan tugas.

Lainnya halnya dengan Martoyo (2001) yang mendefinisikan kepemimpinan sebagai keseluruhan aktifitas dalam rangka mempengaruhi orang-orang untuk bekerjasama dalam rangka mencapai suatu tujuan yang memang diingikan bersama.Dari definisi ini terjadi penekanan dalam hal kerjasama dimana unsur-unsur yang terdapat dalam organisasi menjadi bagian yang amat penting dalam pencapaian aktivitas yang efektif dan pendapat ini diperkuat oleh Timple (2000) yang mendefinisikan kepemimpinan sebagai kegiatan mencoba mempengaruhi orang agar berusaha mencapai sasaran bisnis.

Selain kedua pendapat diatas kepemimpinan oleh para ahli juga banyak didefinisikan menurut perspektif dan aspek fenomena yang menarik, dan biasanya ditinjau berdasarkan sifat, perilaku, pola interaksi, hubungan antar peran, jabatan, administrative dan sebagainya.Seperti menurut Robbins (2001) kepemimpinan adalah kemampuan untuk mempengaruhi suatu kelompok kearah pencapaian tujuan.

Sumber pengaruh tersebut dapat bersifat formal karena kedudukannya dalam organisasi, atau informal karena pembawaan diri.

\section{Keefektifan Kepemimpinan}

Peran pemimpin dalam pertemuan kelompok adalah sebagai pemandu diskusi dan mengarahkan secara konstruktif dalam mencapai pemecahan masalah, sehingga hasil yang dicapai efektif sesuai dengan tujuan yang telah ditetapkan. Adapun kepemimpinan yang efektif menurut Richard (2006) kemampuan seseorang dalam melakukan empat fungsi manajemen yaitu planning (perencanaan), organizing (pengorganisasian), actuating (pengarahan) dan controlling (pengendalian), menggunakan orang lain agar dapat mencapai tujuan yang ditetapkan sebelumnya dengan menggunakan cara yang benar. Pendapat diatas dilengkapi 
kembali oleh pendapat Megan (2005) yang menyebutkan bahwa kepemimpinan yang efektif adalah pemimpin yang mempunyai fungsi sebagai pembuat keputusan, mampu melakukan pengarahan, dan pengkordinasian aktifitas kelompok guna mencapai tujuan yang sesuai. Selain itu kepemimpinan yang efektif juga mampu menangani masalah yang ada dalam organisasinya seperti tekanan, ketegangan, konflik dan lain-lain dengan menggunakan suatu kerangka/struktur kerjasama antar tim.

Adapun penjabaran mengenai efektifitas kepemimpinan kepala sekolah secara khusus diutarakan oleh soebagio (2001) yaitu : Pemimpin yang dalam hal ini adalah kepala sekolah mempunyai kewajiban untuk mengabdikan dirinya dalam 6 (enam) bidang penting yaitu : 1) Orang (guru dan siswa), 2) bantuan alat-alat pengajaran, 3) sumber-sumber yang memadai, 4) kualitas pengawasan, 5) kordinasi, dan 6) pemecahan masalah, dengan menggunakan 4 unsur manajemen yaitu perencanaan, pengarahan, pengkordinasian, dan pengontrolan. Dari definisi ini seorang kepala sekolah yang dipimpinnya mulai dari orang hingga alat (barang) yang ada disekolah dengan menjalankan keempat fungsi manajemen.

Dari seluruh definisi diatas, penulis dapat menyimpulkan bahwa kepemimpinan yang efektif terkhusus bagi seorang kepala sekolah adalah kepemimpinan yang mampu menjalankan seluruh sumberdaya berharga yang ada disekolahnya, mulai dari sumberdaya manusia (guru, siswa dan karyawan) hingga sumberdaya alam (aset-aset berharga yang ada didalam sekolah seperti saranaprasarana, alat-alat peraga, dil) dengan menjalankan keempat fungsi manajemen, yaitu planning (perencanaan), organizing (pengorganisasian), actuating (pengarahan) dan Controling (pengendalian), menggunakan orang lain agar dapat mencapai tujuan yang ditetapkan sebelumnnya.

\section{Kinerja Guru}

Kinerja Guru dalam hal ini tentunya adalah segala sesuatu yang menyangkut tentang kemampuan guru dalam menjalankan proses belajarmengajar dengan segala selukbeluknya. Oleh karena itu ada baiknya jika kita mengetahui terlebih dahulu apa yang dimaksud dengan kemampuan. Kemampuan adalah himpunan sejumlah perilaku yang saling berkaitan yang terbentuk melalui pengalaman belajar dan pelatihan (buku II Pedoman pelaksanaan PPSPTK, 1991).Kemampuan mengajar dapat diklasifikasikan dalam 3 penggolongan, yaitu (1) kompetensi pribadi, (2) kompetensi professional dan (3) kemasyarakatan. 
Dari tiga penggolongan tersebut, maka studi ini hanya memfokuskan pada kompetensi professional, yaitu kompetensi yang langsung berkaitan dengan kemampuan melaksanakan program kegiatan belajar-mengajar.Istilah kompetensi (kemampuan) mempunyai banyak makna Yang jelas, merujuk pada kemampuan melaksanakan sesuatu yang diperoleh melalui pendidikan atau latihan.

Adapun kemampuan mengajar menurut Newton (1995) adalah : 1) kualitas personel dan professional. 2) persiapan mengajar. 3) perumusan tujuan. 4) evaluasi. 5) penampilan didalam kelas, penampilan siswa, selanjutnya kemampuan ini dikelompokkan menjadi lima kluster yaitu 1) kluster perencanaan dan persiapan mengajar, 2) kluster kemampuan mengajar guru dan kemampuan belajar siswa, 3) kluster kemampuan mengumpulkan dan menggunakan informasi hasil belajar, 4) kluster kemampuan hubungan interpersonal, meliputi hubungan siswa, dengan supervisor professional dan kolega guru, 5) kluster hubungan kemampuan tanggung jawab terhadap orant tua, kurikuler, ekstra kurikuler, administrative dan budgetair. Dengan berbagai kemampuan guru diatas disimpulkan bahwa seorang guru yang baik harus mempunyai tiga kelompok besar kemampuan mendasar, yaitu : kemampuan pribadi, kemampuan professional dan kemampuan kemasyarakatan.

Tetapi pada pembahasan kali ini penulis hanya membatasi pada kemampuan professional guru (yaitukluster 1 hingga 3 ) yaitu kluster 1.Perencanaan dan persiapan mengajar 2.Kemampuan mengajar guru dan kemampuan belajar siswa. 3 . Kemampuan menggumpulkan dan menggunakan informasi hasil belajar, sebagai seorang individu yang diukur kemampuannya dalam menjalankan profesinya.

\section{Kerangka Pikir Konseptual}

Tugas pemimpin organisasi sebagai orang yang memegang kendali puncak dalam suatu organisasi adalah untuk dapat menjalankan fungsi-fungsi manajemen dalam organisasi yang dipimpinnya sehingga dapat berjalan dengan baik dan lancar. Dengan

melakukan/menjalankan fungsi manajemen yang dalam hal ini adalah pengarahan dan pengorganisasian pemimpin mampu mengakomodir kebutuhan bawahannya. Apabila kepemimpinan sesorang cukup baik, akan melahirkan hal positif bagi pegawai dalam pekerjaannya sehingga pegawai akan bekerja dengan baik, oleh karena itu sejauh mana keefektifan kepemimpinan akan mempengaruhi kinerja bawahannya. Ternyata hal lain yang juga bedampak pada kinerja bawahannya. 


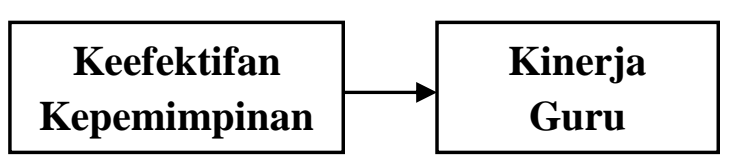

Sehubungan dengan masalahmasalah penelitian yang telah dikemukakan, maka dalam penelitian ini mengemukakan hipotesis = Ada pengaruh antara keefektifan kepemimpinan kepala sekolah terhadap kinerja guru.

Penelitian ini yang mengambil judul pengaruh keefektifan kepemimpinan kepala sekolah terhadap kinerja guru, mempunyai satu variable bebas yaitu kepemimpinan yang menjadi sebab perubahan atau yang mempengaruhi variable terikat dalam hal ini adalah kinerja karyawan.Sedangkan variable terikat adalah variable yang dipengaruhi variable bebas, dalam hal ini kinerja guru disebut sebagai variable terikat.

\section{Keefektifan Pengorganisasian dan Pengarahan Kepala Sekolah}

Keefektifan kepala sekolah dalam pengarahan personil adalah ketepatan kepala sekolah melakukan tugas pengarahan kepada guru-guru untuk melaksanakan tugas mengajarnya. Aspek ini diukur dengan seringnya kepala sekolah untuk memberikan dan menjelaskan perintah, memberi petunjuk, memberi kesempatan untuk meningkatkan pengetahuan dan keterampilan serta memberikan koreksi atas pelaksanaan tugas mengajar guru, bantuan dalam pemecahan masalah, kualitas pengawasan dan penyediaan fasilitas

\section{Kinerja Guru}

Sedangkan kinerja guru adalah kemampuan yang terdiri dari 3 kluster. Kluster 1.Perencanaan dan persiapan mengajar.Kluster 2. Kemampuan mengajar guru dan kemampuan belajar siswa dan 3 . Kemampua mengumpulkan dan menggunakan informasi hasil belajar.

\section{METODE PENELITIAN}

Metode yang digunakan adalah metode penelitian untuk menggambarkan keadaan yang sedang berlangsung dan dianalisis secara kuantitatif dengan alat statistic mengenai hubungan 1 variabel bebas yaitu keefektifan kepemimpinan kepala sekolah (X1), dengan variable terikat yaitu kinerja guru.Penelitian ini dilakukan di SMKN 31 Jakarta Pusat. Penelitian ini mendasarkan pada teori-teori yang ada secara sistematis, terkontrol, empiris, dan kritis serta mengandung arti bahwa penyelidikan ilmiah tertata dengan cara tertentu sehingga penyidikan mempunyai keyakinan kritis tentang hasil penelitian, selain itu menggunakan cara tertentu untuk menguji keyakinannya dengan menghadapkan pada realita yang obyektif. Adapun rancangan/metode ini menggunakan design penelitian hasil rancangan schriesheim, neilder 
dan scandura (academy of management journal, 1998, vol 41 no. 3. 298-318)

Metode deskriftif digunakan untuk mengetahui informasi mengenai rata-rata standar deviasi, persentase dan grafik variable status karyawan dan golongan.

Metode korelasi, rancangan ini diarahkan untuk memberi gambaran kuantitatif mengenai hubungan dan derajat signifikasi hubungan antara variable keefektifan kepemimpinan dan iklim organisasi terhadap kinerja menggunakan uji korelasi spearman sesuai rancangan data berskala likert dikatakan ordinal karena pernyataan Selalu mempunyai tingkat preferensi yang "lebih tinggi" dari Sering, dan Jarang "lebih tinggi" dari "Tidak Pernah". (Ghozali, 2005, P.41)

Teknik Analisis data yang digunakan terhadap data hasil penelitian adalah teknik deskriptif analisis, yaitu suatu metode dalam meneliti kasus sekelompok orang, obyek, kondisi, sistem pemikiran ataupun suatu peristiwa penting pada masa sekarang.Penelitian ini bertujuan membuat deskripsi, gambaran atau lukisan secara sistemati factual dan akurat mengenai fakta, sifat, serta hubungan fenomenal yang diselidiki.

\section{Populasi dan Sampel}

Sesuai dengan pembahasan masalah sebagaimana telah dikemukakan pada bab terdahulu, populasi atau yangmenjadi obyek adalah guru di SMKN 31 Jakarta Pusat yang saat ini berjumlah 55 guru.

Salah satu cara untuk menentukan besarnya sampel dari suatu populasi, dikemukakan oleh slovin yang dikutip Umar (1999, p.108), dengan rumus :

Sampel $(n)=\frac{N}{1+N(e)^{2}}$

( $\mathrm{N}=$ Populasi; $\mathrm{e}=$ persen ketidaktelitian karena kesalahan pengambilan sampel yang masih dapat ditolerir)

Berdasarkan rumus tersebut diatas, dengan taraf kesalahan 5\% atau kepercayaan $95 \%$ dari populasi yang berjumah 55 guru, dapat ditentukan jumlah sampel yang reprentatif yaitu sebanyak 52,25 yng dibulatkan menjadi 52 orang guru

Kekuatan Formasi Guru

\begin{tabular}{|c|c|c|c|c|c|c|c|}
\hline Gol & I & II & III & IV & K2 & $\begin{array}{c}\text { Ho } \\
\text { nor } \\
\text { er }\end{array}$ & $\begin{array}{c}\text { Ju } \\
\text { ml } \\
\text { ah }\end{array}$ \\
\hline Jum & 0 & 0 & 29 & 14 & 1 & 11 & 55 \\
\hline
\end{tabular}

Sample menurut slovin adalah :

$S=\frac{55}{1+55(5 \%)^{2}}=52.25=52$ guru

Sesuai dengan karakteristik populasi dari para guru yang terbagi dalam tingkatan golongan. Maka teknik pengambilan sampel yang digunakan dalam penelitian adalah stratified random sampling, yaitu suatu proses pemilihan sampel sedemikian rupa sehingga populasi pada semua strata terwakili secara 
proporsional pada sampel. Stratifikasi populasi dan penghitungan sampel dapat dilihat dari table berikut :

\begin{tabular}{|c|c|c|c|c|}
\hline $\begin{array}{l}\mathbf{N} \\
\mathbf{0}\end{array}$ & $\begin{array}{l}\text { GOLON } \\
\text { GAN }\end{array}$ & $\begin{array}{l}\text { POPU } \\
\text { LASI }\end{array}$ & $\begin{array}{l}\text { PERHITU } \\
\text { NGAN }\end{array}$ & $\begin{array}{l}\text { JUM } \\
\text { LAH }\end{array}$ \\
\hline 1 & I & 0 & 0 & $\begin{array}{c}0 \\
\text { Guru }\end{array}$ \\
\hline 2 & II & 0 & 0 & $\begin{array}{c}0 \\
\text { Guru }\end{array}$ \\
\hline 3 & III & 29 & $\begin{array}{c}29 \times 52 / \\
55= \\
27,41\end{array}$ & $\begin{array}{c}28 \mathrm{Gu} \\
\mathrm{ru}\end{array}$ \\
\hline 4 & IV & 14 & $\begin{array}{c}14 \times 52 / \\
55= \\
13.23\end{array}$ & $\begin{array}{c}13 \\
\text { Guru }\end{array}$ \\
\hline 5 & K2 & 1 & $\begin{array}{c}1 \times 52 / \\
55=0.94\end{array}$ & $\begin{array}{c}1 \\
\text { Guru }\end{array}$ \\
\hline 6 & $\begin{array}{c}\text { HONOR } \\
\text { ER }\end{array}$ & 11 & $\begin{array}{l}11 \times 52 / \\
55=10,4\end{array}$ & $\begin{array}{c}10 \\
\text { Guru }\end{array}$ \\
\hline & $\underset{\mathbf{H}}{\text { JUMLA }}$ & 55 & & $\begin{array}{c}52 \\
\text { guru }\end{array}$ \\
\hline
\end{tabular}

\section{Pengumpulan Data}

Setelah sampel ditentukan, langkah selanjutny yang perlu dilakukan adalah menentukan tata cara untuk mengumpulkan atay memperoleh data dari orang-orang (responden) yang telah ditetapkan sebagai sampel. Menurut Nazir (1999, p. 212), secara umum metode pengumpulan data dapat dibagi menjadi beberapa kelompok, yaitu :

1. Observasi atau pengamatan langsung adalah cara pengambilan data dengan menggunakan mata tanpa ada pertolongan alat standar lain. Dengan cara observasi ini seorang dapat mencatat secara langsung baik dengan cara berkomunikasi secara langsung maupun tidak langsung. Tetapi diperlukan waktu menunggu yang lama dan tidak semua kegiatan dapat diperoleh hanya dengan pengamatan.

2. Metode dengan menggunakan pernyataan. Dalam metode ini digunakan beberapa cara yaitu dengan cara interview atau wawancara secara langsung dan dengan cara memberikan kuisioner. Intervie adalah proses memperoleh keterangan untuk penelitian dengan cara Tanya jawab sambil bertatap muka. Pertanyaan pada penelitian dengan interview ini lebih bersifat terbuka sehingga peneliti sering mengalami kesulitan dalam melakukan analisa terhadap jawaban responden. Cara lain dalam pengukuran adalah kuisioner atau daftar pertanyaan. Pertanyaan-pertanyaan yang terdapat dalam kuisioner merupakan pertanyaan yang disusun secara sistematis dan dibuat cukup lengkap dan terperinci dengan membatasi respondennya dalam memberikan jawaban kepada beberapa alternative saja, sehingga memudahkan peneliti saat menganalisanya.

Pada penelitian ini penulis menggunakan beberapa teknik pengumpulan data sebagai berikut :

1. Angket atau kuisioner

Dengan mengirimkan daftar pertanyaan/pernyataan yang telah disusun sedemikian rupa 
secara terperinci dan lengkap beserta alternative jawabannya sebagai instrument penelitian kepada responden yang telah ditetapkan sebagai sampel.

2. Wawancara

Untuk melengkapai data yang diperoleh melalui angket, akan dilakukan wawancara secara langsung dengan guru-guru serta kepada sekolah dan staf yang mempunyai latar belakang, status dan golongan sesuai dengan topic penelitian.

\section{Uji Normalitas Data}

Dalam penelitian ini juga penting dilakukan normalitas data dengan tujuan untuk mengetahui apakah data terdistribusi secara normal atau tidak, untuk uji normalitas data menggunakan statistic skewness-kurtosis data tersebut dapat dikatakan normal apabila memiliki tingkat signifikan jika nilai berada diantara -2 sampai +2 (Santoso, 2001).

\section{Uji Validitas}

Uji validitas dilakukan dengan analisis faktor dimaksudkan untuk memastikan bahwa masing-masing pertanyaan akan terklarifikasi pada variable-variabel yang telah ditentukan (contruct validity). Uji analisis ini dapat dilakukan terhadap nilai setiap variable dengan extraction method, principalcomponent dan setiap komponen memiliki faktor loading lebih besar dari 0,5 (Santoso, 2001).

\section{Uji Reliabilitas}

Uji realibilitas dimaksudkan untuk mengetahui sejauh mana hasil pengukuran terhadap konsistensi, apabila dilakukan pengukuran dua kali atau lebih terhadap gejala yang sama dengan menggunakan alat pengukuran yang sama. Uji realibilitas dengan menggunakan Cronbach's Alpha dari masing-masing instrument dalam suatu variable. Instrumen yang dipakai dalam variable tersebut dikatakan reliabel apabila memiliki Cronbach's Alpha lebih dari 0.05 (Santoso, 2001).

\section{Uji Normalitas}

Uji normalitas bertujuan untuk menguji apakah dalam model regresi, variabel terikat dan variabel bebas keduanya mempunyai distribusi normal atau tidak.

\section{Uji Hipotesis}

Dalam penelitian ini, peneliti menggunakan metode uji parametrik dengan alasan karena sampel dari penelitian ini berjumlah lebih dari 30 sampel (> 30 sampel), (Indriantoro \&Supomo, 1999:200).Uji parametrik dilakukan untuk menguji hipotesis.Peneliti menguji hipotesis menggunakan pendekatan metode regresi sederhana (simple regresion).Model ini digunakan untuk menganalisis hubungan antara satu variabel indpenden dengan variabel dependen. 


\section{HASIL DAN PEMBAHASAN Pengujian Validitas}

Pengujian validitas dilakukan dengan melihat nilai pada output komponen matrik, dengan keputusan yang diambil adalah :

Jika nilai faktor loading pada component matrix > 0.5.maka valid Jika nilai faktor loading pada component matrix <0.5.maka tidak valid

\section{Uji Reliabilitas}

Pengujian reliabilitas dilakukan dengan melihat besarnya hasil dari nilai Cronbach alpha, dengan keputusan sebagai berikut (Ghozali, 2005) :

Jika, Cronbach alpha > 0.6, maka reliabel

Jika, Cronbach alpha < 0.6, maka tidak reliabel

\section{Pengujian Reliabilitas}

\begin{tabular}{|c|c|c|c|}
\hline Variabel & $\begin{array}{c}\text { Cronbach } \\
\text { Alpha }\end{array}$ & $\mathbf{N}$ & Hasil \\
\hline $\begin{array}{c}\text { Keefektifan } \\
\text { Kepemimpi } \\
\text { nan }\end{array}$ & 0.8987 & 23 & Reliabel \\
\hline
\end{tabular}

Tabel diatas menjelaskan mengenai pengujian realibilitas terhadap 1 variabel penelitian untuk data responden penelitian yaitu didapat nilai untuk variabel Keefektifan Kepemimpinan sebesar 0.8987.dengan demikian dapat diambil kesimpulan bahwa variabel penelitian tersebut dianggap reliabel.

\section{Uji Normalitas}

Uji normalitas bertujuan untuk menguji apakah dalam model regresi, variabel terikat dan variabel bebas keduanya mempunyai distribusi normal atau tidak.Pengujian juga dilakukan dengan menggunakan skewness dan kurtosis dengan hasil seluruh variabel pernelitian berada dianatara -2 sampai dengan 2.Dengan demikian dapat diperoleh kesimpulan bahwa data-data di dalam penelitian ini seluruhnya berdistribusi normal.

\section{Uji Hipotesis}

Pengujian hipotesis = Ada pengaruh keefektifan kepemimpinan kepala sekolah terhadap kinerja guru.

\section{Analisa Regresi Hipotesis}

Model summary

\begin{tabular}{|l|l|l|l|c|}
\hline Model & $\mathrm{R}$ & $\begin{array}{c}\mathrm{R} \\
\text { Squ } \\
\text { are }\end{array}$ & $\begin{array}{c}\text { Adjuste } \\
\mathrm{d} \mathrm{R} \\
\text { Square }\end{array}$ & $\begin{array}{c}\text { Std. } \\
\text { Error of } \\
\text { the } \\
\text { Estimat } \\
\mathrm{e}\end{array}$ \\
\hline 1 & $.933^{\mathrm{a}}$ & .871 & .869 & 2.964 \\
\hline a. & \multicolumn{3}{|c}{ Predictors (Constant) }
\end{tabular}

Keefektifan Kepemimpinan

Tabel diatas menjelaskan bahwa nilai yang dihasilkan untuk correlation coefficient (R) adalah sebesar 0.933, dimana nilai tersebut berarti bahwa terdapat hubungan yang sangat kuat antara keefektifan kepemimpinan kepala sekolah dengan kinerja guru dikarenakan nilai $\mathrm{R}$ berada di antara nilai $0,80-1,000$. (Sugiono, 2004) Sedangkan untuk nilai coefficient of determination 
(Adjusted $R$ Square) diperoleh nilai sebesar 0.869 dimana hal tersebut berarti yang berarti $86,9 \%$ variasi dari variabel keefektifan kepemimpinan kepala sekolah dapat menjelaskan kinerja guru, sedangkan sisanya $13.1 \%$ variasi kinerja guru yang dijelaskan oleh variabel-variabel lain yang tidak terdapat pada model regresi penelitian.

\section{Analisis Hasil dan Interpretasi}

Hipotesis yang dirumuskan dalam penelitian ini telah dibahas.Hal ini menunjukkan bahwa pengaruh keefektifan kepemimpinan $\left(\mathrm{X}_{1}\right)$ memiliki pengaruh terhadap kinerja guru.

Adapun hasil penelitian yang penulis lakukan tentang pengaruh antara keefektifan kepemimpinan $\left(\mathrm{X}_{1}\right)$ terhadap kinerja guru $(\mathrm{Y})$ pada SMKN 31 Jakarta Pusat adalah sebagai berikut :

1. Variabel keefektifan kepemimpinan mempunyai korelasi positif terhadap kinerja guru sebesar $r X_{1} Y_{1}=0,933$. Pada tabel Analisa Regresi Hipotesis menunjukkan hubungan yang kuat diantara ketiga variabel diatas.

Dari hasil penelitian tersebut dapat diinterpretasikan sebagai berikut :

1. Keefektifan kepemimpinan $\left(X_{1}\right)$ berpengaruh nyata terhadap kinerja guru. Hipotesis yang diajukan adalah terdapat pengaruh anatara keefektifan kepemimpinan terhadap kinerja guru yang dapat di terima.
Hubungan positif yang digambarkan dalam penelitian kuantitatif diatas, dapat di gambarkan oleh hasil penelitian kualitatif. Semakin baik diterapkannya keefektifan kepemimpinan (X1) akan berdampak positif terhadap kinerja guru $(Y)$, dengan kata lain kinerja dikaryawan di SMKN 31 Jakarta Pusat, dipengaruhi oleh faktor keefektifan kepemimpinan.

Kinerja karyawan sebagai suatu kondisi di mana setiap tugas yang dilakukan oleh pegawai senantiasa mencapai sasarannya sesuai dengan ketentuan yang telah ditetapkan. Kinerja sebagai rasio dari output dari keberhasilan sebuah perusahaan / organisasi.Dengan kinerja yang tinggi berarti mampu mencapai sasaran yang telah ditetapkan.

\section{KESIMPULAN}

Berdasarkan pada hasil analisis dan pembahasan serta sebagai pembuktian kebeneran hipotesis yang dirumuskan yang dilakukan penulis pada pembahasan sebelumnya.dan dapat disimpulkan bahwa ada pengaruh yang signifikan antara keefektifan kepemimpinan kepala sekolah terhadap kinerja guru.

Implikasi manajerial yang disajikan dalam penelitian ini adalah pembuat keputusan dalam kebijakandisekolah dalam hal ini adalah kepala sekolah di harapkan mampu menentukan strategi yang lebih baik dan tepat agar sesuai 
dengan apa yang diinginkan oleh para guru, sehingga kinerja guru meningkat.

Untuk Implikasi Manajerial (kepala sekolah) yang kedua adalah agar kepala sekolah dapat selalu melaksanakan pengarahan yang intensif kepada guru-guru.

Sedangkan Implikasi terhadap kinerja guru adalah kurangnya kemampuan guru dalam memberikan ekpresi komunikasi lisan dan tulisan yang baik kepada siswa, diharapkan dengan kepemimpinan kepala sekolah yang baik maka guru mampu melakukan hal tersebut dengan baik.

\section{DAFTAR PUSTAKA}

Atmojo, Soebagio. (2001). Kepemimpinan Kepala Sekolah.Semarang : CV. Adhi Waskita

Crawford, Megan (2005). Leadership And Teams In Educational Management. Jakarta : Grasindo Departemen Pendidikan Dan Kebudayaan R.I. (1991). Pedoman Pelaksanaan Pola Pembaharuan System Pendidikan Tenaga Kependidikan Di Indonesia. Buku II. Jakarta : Dikjen DIKTI.

Draf, L Richard.(2006). Management.Jakarta : Salemba.

Ghozali, Imam. (2005). Aplikasi Analisis Multivariate dengan program SPSS, badan penerbit universitas

Diponogoro. Semarang.

Indriantoro, N., dan Supomo, Bambang.(1999). Metodologi
Penelitian
Bisnis
Untuk
Akuntansi
dan
Manajemen.Yogyakarta : BPFE.

Martoyo, Susilo. (2001). Manajemen

Sumber

Daya

Manusia.Yogyakarta : BPFE.

Nawawi, Hadari H. (1999). Manajemen Sumber Daya Manusia, Untuk Bisnis yang Kompetitif. Yogyakarta : Universitas Gajah Mada.

Newton, E.H And Brathwaite. (1995). Prioritas And Program Effectiveness In Teacher Education : A Study Of Perception of Teachers In Training And Their Tutors In Teaching And Teacher Education. Volume 4.

Portnoy, Robert. (2001). Leadership For Competencies for Success. Newjersey : Prentice Hall.

Santoso, J. (2000). Statistik: Teori dan aplikasi. Edisi kelima, jilid 1.Jakarta : Erlangga.

Sergiovanni, T.J. (1997). The Principalhip : A Reflective Practice Perspective. Newton Massachussetts : Allyn And Bacon Inc.

Stoner, J.F. (2001).Management.Newyork : Prentice-Hall. Inc

Sugiono.(2001).

Metode Penelitian.Bandung : Alfabeta.

Supranto.(2000). Metode Analisa Data.Jakarta : PT. Gramedia.

Santoso.J (2000).Statistik : Teori dan Aplikasi. Edisi kelima, jilid 1.Jakarta : Erlangga. 
Terry, G.R. (1998). Principles of Management. Illinois : Homewood.

Timple,

A.

(2000).

Kepemimpinan.Jakarta : PT. Gramedia.

Irawan.Sukma (2002) Analisis Tentang Iklim Organisasi. Kepemimpinan Dan Kepuasan Kerja. Jakarta : Universitas Indonesia.
Kauzes dan Posner.(1998). Empat Perilaku Kepemimpinan yang Efektif.Jakarta : Universitas Indonesia.

Simanjuntak, Pinondang (1997). Pengaruh Kepuasan Kerja. Iklim Organisasi Dan Kepemimpinan Terhadap Kualitas Pelayanan Kantor Kelurahan Di Kota Madya Jakarta Pusat.Jakarta : Universitas Indonesia. 